\title{
Autogrooming by resistant honey bees challenged with individual tracheal mites
}

\author{
Robert G. DANKA*, José D. VILLA \\ USDA ARS Honey Bee Breeding, Genetics and Physiology Laboratory, 1157 Ben Hur Road, Baton Rouge, \\ Louisiana 70820 , USA
}

(Received 16 August 2002; revised 6 March 2003; accepted 28 April 2003)

\begin{abstract}
Autogrooming responses of resistant and susceptible strains of honey bees were measured when bees were challenged by placing adult female tracheal mites on their thoraces. Marked, young adult workers of the two strains of bees were added to colonies in observation hives. We transferred a single, live, adult, female mite onto the mesoscutum of a marked bee, monitored the bee for seven minutes and then removed it and searched for the mite. Greater proportions of resistant bees autogroomed, and resistant bees made more grooming attempts. Bees of both strains had equal apparent grooming effectiveness; grooming bees lost approx. $75 \%$ of mites. Control-group bees (those only stroked with the brush used to transfer mites) of the two bee strains did not differ in any response parameter. Resistant bees may have a lower threshold for responding by autogrooming when stimulated by mites on their body.
\end{abstract}

Apis mellifera / honey bees / Acarapis woodi / tracheal mites / genetic resistance / grooming behavior

\section{INTRODUCTION}

Some genetic strains of honey bees, Apis mellifera L., resist damaging infestations of parasitic tracheal mites, Acarapis woodi (Rennie) (reviewed in Danka, 2001). Evidence suggests that resistance is largely founded on the ability of individual worker bees to groom and rid themselves of mites that are migrating from old to new host bees. This trait of autogrooming was determined by deduction to be a mechanism of resistance following observations of grooming dances (Pettis and Pankiw, 1998) and by experiments involving amputation of the legs used to groom (Danka and Villa, 1998). Resistance appears to be regulated little if at all by allogrooming (i.e., nestmates cleaning each other; Pettis and Pankiw, 1998), hairs surrounding bee spiracles (Danka and Villa, 1999) or the cuticular chemistry of bees (van Engelsdorp and Otis, 2001).

We report here tests of responses of genetically resistant and susceptible strains of bees when the bees were challenged directly by placing adult female tracheal mites on their thoraces. Our observations offer further evidence of the contribution of autogrooming to resistance.

\section{MATERIALS AND METHODS}

\subsection{Honey bee colonies}

Six experimental trials, with two colonies per trial, were conducted in spring and autumn 1997 and spring 1998. Two days before the start of observations in each trial, two colonies were established in observation hives that held two

\footnotetext{
* Corresponding author: rdanka@ars.usda.gov
} 
medium depth $(16 \mathrm{~cm})$ Langstroth combs. The lower comb had brood of all stages and the upper comb held honey. Each colony was started with a queen and with enough worker bees (approx. 1000) to cover the brood on the lower comb and partially cover the upper comb. The bees came from two colonies not related to the resistant and susceptible bees used in the test. These colonies had been treated with menthol (a non-persistent volatile) to control tracheal mites at least several months earlier, and samples of 50 worker bees per colony revealed no infestation when observation hive colonies were set up. The observation hives were located indoors with entrances for bees through a north-facing window; observations were made under fluorescent light and daylight.

Each colony also was given young worker bees from each of two genetic strains. One strain was resistant to tracheal mites and the other was susceptible. These strains are known from our previous studies to differ consistently in their susceptibility to tracheal mite infestation (see Danka and Villa, 1998, and references therein). Strains had been maintained as closed populations by propagating at ca. 18-month intervals. The resistant colonies were never given treatments for tracheal mites, but the susceptible colonies were treated occasionally to avoid death or severe damage from mite infestation. Four resistant colonies and three susceptible colonies were used as sources of young, test bees in the six, 3-day trials. On the evening before the start of each trial, combs with emerging bees from a resistant colony and a susceptible colony were cleaned of adult bees at 18.00 hours, caged separately, and held in an incubator at $35^{\circ} \mathrm{C}$ and $50 \%$ RH. At $21.00,00.00$ and 03.00 hours, 20 newly emerged resistant bees and 20 susceptible bees were given individually identifiable marks of enamel paint on their abdominal tergites, and half of each group was added to each of the two observation hives. Subsets of this cohort of 120 marked bees were used for testing during the next three days. Bees had a median adult age of 12 hours (range of 7-20 hours) when observations were made between 10.00 and 14.00 hours on the next day; other bees were about ca. $1 \frac{1}{1} 2$ days old and $2 \frac{1}{2}$ days old on the subsequent two days. A total of 555 of the 720 marked bees was used for observations throughout all trials.

\subsection{Tracheal mite challenge and observations}

During each daily observation session from 10.00-14.00 hours, tracheae of mite-infested bees (collected from other sources) were excised and kept on a microscope slide in a covered petri dish; the dish contained wet filter paper to provide a high
RH. To infest a bee, a trachea was dissected at ca. 40X magnification and an adult female mite was lifted out on the tip of a human eyelash mounted on a stick. Mites were selected by their large size, conformation and light amber color. The mite was deposited lateral to the midline of the mesoscutum of a resistant or susceptible bee while these bees were in situ in the colony. Access to bees was through four, 9- X 5-cm, hinged, magnetically secured doors which were built into each of the two acrylic sides of the hives.

After depositing a mite, the observer monitored the activities of the test bee for seven min. Preliminary observations showed that within seven min almost all autogrooming responses to mites occurred, and mites did not reach and enter spiracles. Notes were made of time of initiation, position (treated or untreated side) and number of grooms made to the thorax. A groom consisted of the bee moving a mesothoracic leg anteriorly across the thorax; the tibia combed the pleura and the basitarsus combed the nota. A grooming episode was one or more grooms separated from other grooms by $>15$ s. After seven min, we caught the bee and attempted to locate the mite using 40-60X magnification. Tested bees were not returned to the colony.

A set of control observations was made to estimate response to simple stimulation by the eyelash brush. Control bees were "treated" by stroking once on one side of the mesoscutum.

All observations were made by two people; each person tested the bees in one colony in each trial. Resistant and susceptible bees generally were tested alternately within each colony during each daily observation session. A total of approx. 20 bees (including 15-18 treated bees and 2-5 control bees) were tested each day in each colony.

\subsection{Statistical analyses}

Chi-square tests were used to evaluate differences between class variables for categorical data (proportions of different types of bees responding). For continuous variables (time, numbers of grooms), differences between class means were evaluated with $t$-tests. Homogeneity of categorical grooming responses through the six trials and the three days was assessed with Breslow-Day tests (PROC FREQ of SAS) (SAS, 1989).

\section{RESULTS}

When challenged by mites, a greater proportion of resistant bees than susceptible bees groomed (0.62 vs. 0.49, respectively; Tab. I, Sect. I). A greater proportion of 
Table I. Comparisons of autogrooming responses of resistant and susceptible bees when bees were treated by placing a tracheal mite on the mesoscutum. Section I of the table involves all bees so treated. Section II involves bees of this treated group that subsequently autogroomed. Section III involves control bees which were "treated" by stroking one time with the same brush used to transfer mites to treated bees. Only variables that showed differences between strains in Sections I or II are presented in Section III. Probabilities of differences between bee strains are from chi-square tests for proportional data and from $t$ tests for continuous data; continuous data are given as mean \pm SE. Data for bees listed as having groomed on the treated side include bees which groomed on both sides.

\begin{tabular}{|c|c|c|c|}
\hline Response parameter & $\begin{array}{c}\text { Resistant } \\
\text { bees }\end{array}$ & $\begin{array}{l}\text { Susceptible } \\
\text { bees }\end{array}$ & $P$ \\
\hline \multicolumn{4}{|l|}{ I. Treated bees } \\
\hline$n$ & 279 & 276 & - \\
\hline Proportion $(n)$ that groomed & $0.62(174 / 279)$ & $0.49(135 / 276)$ & 0.002 \\
\hline $\begin{array}{l}\text { Proportion }(n) \text { that had no mite } \\
\text { after grooming }\end{array}$ & $0.75(131 / 174)$ & $0.77(104 / 135)$ & 0.636 \\
\hline $\begin{array}{l}\text { Proportion }(n) \text { that had no mite } \\
\text { after no grooming }\end{array}$ & $0.67(70 / 105)$ & $0.57(80 / 141)$ & 0.117 \\
\hline $\begin{array}{l}\text { Proportion }(n) \text { that groomed on } \\
\text { the treated side }\end{array}$ & $0.51(89 / 174)$ & $0.37(50 / 135)$ & 0.002 \\
\hline $\begin{array}{l}\text { Proportion }(n) \text { that groomed on } \\
\text { the treated side and had no mite }\end{array}$ & $0.81(72 / 89)$ & $0.82(41 / 50)$ & 0.803 \\
\hline II. Treated bees that groomed & & & \\
\hline$n$ & 174 & 135 & - \\
\hline Total number of grooms & $11.6 \pm 1.2$ & $5.9 \pm 0.6$ & $<0.001$ \\
\hline $\begin{array}{l}\text { Number of grooms on the treated } \\
\text { side }\end{array}$ & $7.6 \pm 0.9$ & $3.8 \pm 0.4$ & $<0.001$ \\
\hline $\begin{array}{l}\text { Number of grooming episodes on } \\
\text { the treated side }\end{array}$ & $1.7 \pm 0.1$ & $1.2 \pm 0.1$ & $<0.001$ \\
\hline Time to first groom & $141 \pm 9 \mathrm{~s}$ & $154 \pm 10 \mathrm{~s}$ & 0.330 \\
\hline $\begin{array}{l}\text { Time to first groom on the } \\
\text { treated side }\end{array}$ & $206 \pm 13 s$ & $236 \pm 15 s$ & 0.143 \\
\hline III. Control bees & & & \\
\hline$n$ & 89 & 74 & - \\
\hline Proportion $(n)$ that groomed & $0.52(46 / 89)$ & $0.46(34 / 74)$ & 0.470 \\
\hline $\begin{array}{l}\text { Total number of grooms (for bees } \\
\text { that groomed) }\end{array}$ & $5.2 \pm 0.8$ & $4.9 \pm 0.8$ & 0.765 \\
\hline $\begin{array}{l}\text { Proportion }(n) \text { that groomed on } \\
\text { the "treated" side }\end{array}$ & $0.42(37 / 89)$ & $0.38(28 / 74)$ & 0.628 \\
\hline $\begin{array}{l}\text { Number of grooms on the "treated" } \\
\text { side (for bees that groomed) }\end{array}$ & $3.0 \pm 0.7$ & $2.7 \pm 0.6$ & 0.730 \\
\hline $\begin{array}{l}\text { Number of grooming episodes on } \\
\text { the "treated" side }\end{array}$ & $1.1 \pm 0.1$ & $1.0 \pm 0.1$ & 0.631 \\
\hline
\end{tabular}

resistant bees also groomed on the treated side (resistant, 0.51; susceptible, 0.37). Resistant bees had 29\% more grooming episodes on the treated side, and about twice as many total grooms and grooms on the treated side (Tab. I, Sect. II). Resistant bees and susceptible bees began grooming, and began grooming on the treated side, at similar 
intervals after mites were transferred (typically 2.5 to $3.5 \mathrm{~min}$ ).

The main categorical grooming responses were consistent throughout the six trials $\left(\chi^{2}=\right.$ 3.647, $d f=5 ; P=0.601)$. There also was consistency across the three days of the test period $\left(\chi^{2}=3.570, d f=2 ; P=0.168\right)$.

Considering both bee strains together, mites were found on smaller proportions of bees that groomed than on bees that did not groom (0.24 vs. $\left.0.39 ; \chi^{2}=13.27, d f=1 ; P<0.001\right)$. However, the apparent success of grooming did not differ between bee strains; about threefourths of both resistant bees and susceptible bees that groomed did not have a mite after seven min (Tab. I, Sect. I). Similarly, bees of the two types that groomed on the treated side had equal frequencies of mite loss (approx. $80 \%$ ).

Among bees that did not groom, there still was a large loss of mites (overall 62\%; Tab. I, Sect. I). There was a tendency $(P=0.117)$ for non-grooming resistant bees to lose more mites than non-grooming susceptible bees. This suggests that the resistant bees may have avoided infestation by mechanisms in addition to autogrooming, but we generally did not address other possibilities. We did note that allogrooming occurred only in approx. 3\% $(16 / 555)$ of the bees we challenged with mites.

Similar proportions of control bees of the two strains groomed (Tab. I, Sect. III). Total numbers of grooms, number of grooms on the treated (stimulated) side and number of grooming episodes on the treated side did not differ between the bee strains for control bees as they did for treated bees. There was a trend among resistant bees for bees treated with mites to be more likely to groom than control bees $\left(\chi^{2}=3.07, d f=1 ; P=0.080\right)$, but no such trend occurred among susceptible bees $\left(\chi^{2}=0.23, d f=1 ; P=0.631\right)$. Even greater differences between treated and control bees for each of the two bee strains were found for total number of grooms and number of grooms on the treated side $(P \leq 0.011$ for these parameters for resistant bees versus $P \geq 0.226$ for susceptible bees). Overall, resistant bees seemed to be relatively more responsive than susceptible bees were to a mite than to a brush stroke.

\section{DISCUSSION}

These data help define the autogrooming response of bees that have genetic resistance to tracheal mites. When resistant bees and susceptible bees were challenged equally by placing a mite directly on the thorax, more resistant bees responded with autogrooming, especially on the infested side, and resistant bees groomed more persistently. This information builds on prior knowledge that resistant bees become relatively more infested than susceptible bees when their ability to groom is reduced by removing or restraining mesothoracic legs (Danka and Villa, 1998), and that more grooming dances (which incorporate autogrooming) occur in the presence of tracheal mites and subsequently help to reduce mite infestation (Pettis and Pankiw, 1998).

Our results raise the possibility that the resistant bees we studied have lower thresholds for the release of autogrooming in response to the stimulus of a migrating tracheal mite. Lower response thresholds could account for both more bees responding and more grooming attempts by those bees. Pettis and Pankiw (1998) postulated something very similar, viz., that bees apt to perform grooming dances have a lower threshold for responding to mites. We found this putative lower response threshold to be related only to the presence of mites, not to the application of the control stimulus; the brush-stroke stimulation of control bees elicited grooming at similar levels by the bee strains, although resistant bees did have a numeric tendency to groom more when stimulated. It would be interesting to see if another general stimulus, such as a dust, could be used to easily discern differing levels of resistance among groups of bees. A simple assay using a common, inert stimulus would be a useful tool in selection and breeding of tracheal mite resistance.

Despite more grooming, resistant bees lost only moderately more mites than susceptible bees lost $\left(72 \%\right.$ vs. $67 \%$, respectively; $\chi^{2}=$ $1.55, d f=1 ; P=0.213$ ) during these 7 -min tests. This result is somewhat unexpected because (1) grooming was shown to increase mite loss, and (2) a greater proportion of resistant bees groomed. The lack of a large difference probably came about from the obscuring effects of a generally high rate of mite loss, 
even in non-grooming bees. This large loss of mites may be normal or may have been a consequence of our artificial handling of mites (e.g., by using mites not physiologically ready to migrate). Although we did not dissect test bees, we feel (based on our preparatory observations) that it is unlikely that mites disappeared into the spiracles during the 7-min tests. We do expect, however, that the difference in mite retention that we saw after just very short periods of observation of individual resistant and susceptible bees would be compounded as potential host bees are repeatedly challenged by tracheal mites during the first few days of their lives.

\section{ACKNOWLEDGEMENT}

We thank Deborah Boykin (USDA, ARS; Stoneville, MS) for advice about statistical analysis. This work was completed in cooperation with the Louisiana Agricultural Experiment Station.

Résumé - Auto-toilettage par des abeilles résistantes confrontées individuellement à Acarapis woodi. Il a été suggéré que l'auto-toilettage par les ouvrières d'abeilles pouvait être un mécanisme utilisé par certaines lignées génétiques d'abeilles domestiques pour résister aux dégâts causés par des niveaux d'infestation élevés par les acariens des trachées, Acarapis woodi (Rennie). Nous avons mesuré les réactions d'auto-toilettage de lignées d'abeilles résistantes et sensibles lorsque des abeilles dans une ruche d'observation étaient directement confrontées aux acariens, qui avaient été déposés sur elles. Des ouvrières naissantes des deux lignées ont été marquées à la peinture et ajoutées à une colonie d'abeilles non apparentées. Des acariens femelles adultes vivants ont été prélevés dans les trachées d'autres abeilles et un seul acarien a été transféré (par des portes d'accès dans les parois de la ruche) à l'aide d'un fin pinceau sur le mésoscutum d'une abeille marquée âgée d'environ $1 / 2 \mathrm{j}, 1 \mathrm{j} 1 / 2$ ou $2 \mathrm{j} 1 / 2$. Nous avons suivi les actions d'auto-toilettage durant $7 \mathrm{~min}$, puis retiré l'abeille et cherché l'acarien. Nous avons ainsi testé 279 abeilles résistantes et 276 abeilles sensibles au cours de 6 essais de $3 \mathrm{j}$. Des proportions plus importantes d'abeilles résistantes se sont toilettées, en particulier sur le côté où l'acarien avait été placé et elles l'ont fait de façon plus continue. Les abeilles des deux lignées ont eu une efficacité apparente de toilettage équivalente, puisque dans les deux cas les abeilles ayant effectué un toilettage ont perdu environ $75 \%$ des acariens. Les abeilles témoins (celles uniquement frappées par le pinceau) des deux lignées n'ont pas montré de différence pour aucun des paramètres.
Les abeilles résistantes ont peut-être un seuil plus bas pour répondre par l'auto-toilettage lorsqu'elles sont stimulées par la présence d'acariens sur leur corps, ce qui permet à un plus grand nombre d'abeilles d'entamer le toilettage et de le faire plus longtemps.

Apis mellifera / Acarapis woodi / résistance génétique / comportement de toilettage

Zusammenfassung - Putzverhalten von resistenten Honigbienen bei Kontakt mit einzelnen Tracheenmilben. Selbstreinigung von einzelnen Arbeiterinnen der Honigbienen (autogrooming) wurde als ein Mechanismus angesehen, der bei einigen genetischen Linien der Honigbienen (Apis mellifera L.) dazu führt, dass die Schadensschwelle durch die Infektion mit Tracheenmilben nicht erreicht wird. Wir haben die Reaktion der Selbstreinigung bei resistenten und empfindlichen Linien von Bienen im Beobachtungsstock gemessen, hierzu wurden Tracheenmilben direkt auf die Bienen gesetzt. Frisch geschlüpfte, adulte Bienen von beiden Linien wurden mit Enamelfarbe markiert und in ein Volk mit unverwandten Bienen gesetzt. Lebende adulte Milbenweibchen wurden aus anderen Bienen herauspräpariert und eine einzelne Milbe wurde (durch eine seitliche Öffnung) mit einem feinen Pinsel auf das Mesoscutum einer markierten Biene gesetzt, die entweder ca. $1 / 2,1 \frac{1}{2}$ or $21 / 2$ Tag alt waren. Wir protokollierten 7 Minuten lang die Putzreaktionen der befallenen Biene, dann fingen wir die Biene und suchten nach der Milbe. Dieser Vorgang wurde mit 279 resistenten und 276 empfindlichen Bienen sechsmal in 3 Tagesversuchen wiederholt. Ein größerer Anteil der resistenten Bienen putzte sich, besonders an der Seite, auf die die Milbe gesetzt wurde, außerdem putzten sich die resistenten Bienen ausdauernder. Bienen beider Linien waren offensichtlich gleich erfolgreich beim Putzen, die putzende Bienen beider Linien verloren etwa $75 \%$ der Milben. Bienen der Kontrollgruppe beider Linien, die nur mit dem Pinsel berührt wurden, unterschieden sich in keinem der gemessenen Parameter. Resistente Bienen könnten eine niedrigere Schwelle in der Reaktion für das Putzen haben, wenn sich eine Milbe auf ihrem Körper befindet. Dadurch würden mehr Bienen zum Putzen veranlasst, außerdem würde ein längeres Putzen initiiert.

Apis mellifera / Acarapis woodi / Tracheenmilben / genetische Resistenz / Putzverhalten

\section{REFERENCES}

Danka R.G. (2001) Resistance of honey bees to tracheal mites, in: Webster T.C., Delaplane K.S. (Eds.), Mites of the Honey Bee, Dadant \& Sons, Hamilton, Illinois, pp. 117-129. 
Danka R.G., Villa J.D. (1998) Evidence of auto grooming as a mechanism of honey bee resistance to tracheal mite infestation, J. Apic. Res. 37, 39-46.

Danka R.G., Villa J.D. (1999) Paravestibular hairs of British Buckfast honey bees do not regulate genetic resistance to Acarapis woodi, J. Apic. Res. 38, 221-223.

Pettis J.S., Pankiw T. (1998) Grooming behavior by Apis mellifera $\mathrm{L}$. in the presence of Acarapis woodi (Rennie) (Acari: Tarsonemidae), Apidologie 29, 223-235.

SAS Institute (1989) SAS/STAT User's Guide, version 6, 4th ed., Vol. 1. SAS Institute, Cary, NC, USA.

van Engelsdorp D., Otis G.W. (2001) The role of cuticular compounds in the resistance of honey bees (Apis mellifera) to tracheal mites (Acarapis woodi), Exp. Appl. Acarol. 25, 593-603. 